\title{
From rapalogs to anti-aging formula
}

\author{
Mikhail V. Blagosklonny \\ ${ }^{1}$ Cell Stress Biology, Roswell Park Cancer Institute, Buffalo, NY, USA \\ Correspondence to: Mikhail V. Blagosklonny, email: mikhail.blagosklonny@roswellpark.org or blagosklonny@rapalogs.com \\ Keywords: lifespan, longevity, rejuvenation, health, diseases \\ Received: February 17, $2017 \quad$ Accepted: April 30, $2017 \quad$ Published: May 22, 2017
}

Copyright: Blagosklonny et al. This is an open-access article distributed under the terms of the Creative Commons Attribution License (CCBY), which permits unrestricted use, distribution, and reproduction in any medium, provided the original author and source are credited.

\section{ABSTRACT}

Inhibitors of $\mathbf{m T O R}$, including clinically available rapalogs such as rapamycin (Sirolimus) and Everolimus, are gerosuppressants, which suppress cellular senescence. Rapamycin slows aging and extends life span in a variety of species from worm to mammals. Rapalogs can prevent age-related diseases, including cancer, atherosclerosis, obesity, neurodegeneration and retinopathy and potentially rejuvenate stem cells, immunity and metabolism. Here, I further suggest how rapamycin can be combined with metformin, inhibitors of angiotensin II signaling (Losartan, Lisinopril), statins (simvastatin, atorvastatin), propranolol, aspirin and a PDE5 inhibitor. Rational combinations of these drugs with physical exercise and an anti-aging diet (Koschei formula) can maximize their anti-aging effects and decrease side effects.

At first, the discovery of anti-aging properties of rapamycin was met with skepticism because it challenged the dogma that aging is a decline driven by molecular damage caused by free radicals. By now, rapamycin has been proven to be an anti-aging drug. In contrast, antioxidants failed in clinical trials [1-9] and the dogma was shattered [1, 2, 10-18]. In the last decade, anti-aging effects of rapamycin have been confirmed. Anti-aging doses and schedules can be extrapolated from animal studies. Welltolerated doses with minimal side effects can be deducted based on clinical use of rapalogs. So optimal anti-aging doses/schedules can be suggested. Given that rapamycin consistently extends maximal lifespan in mice, rapamycin will likely allow mankind to beat the current record of human longevity, which is 122 years. Yet, rapamycin will not extend life span as much as we might wish to.

Now is the time for anti-aging drug combinations. For example, metformin is currently undergoing repurposing as an anti-aging agent. Several other existing drugs can be re-purposed. Now we can design an antiaging formula, using drugs available for human use. However, we must first discuss the link between growth, aging and age-related diseases.

\section{MTOR: from growth to aging}

It was theoretically predicted that stimulation of mitogenic/growth pathways in arrested or quiescent cells must lead to senescence [19]. This conversion from quiescence to senescence is called geroconversion [2022]. Cellular senescence is a futile growth, a continuation of cellular growth when actual growth is restricted [21, $23,24]$. Growth-stimulation of arrested cells causes their hypertrophy and hyperfunctions (for example, hypersecretory phenotype or SASP in senescent fibroblasts).

This can be applied to organismal aging. When developmental growth is completed, then mTOR (mammalian Target of Rapamycin) and some other signaling pathways) drives organismal aging $[1,15,25$, 26]. These pathways stimulate cellular functions, leading to hyperfunctions (for example, hypertension). Secondary, hyperfunctions can lead to loss of functions [1, 27]. Hyperfunction theory links growth, aging and age-related diseases [1]. Suppression of aging prevents or delays agerelated diseases [17, 28-30].

Age-related diseases are manifestations of advanced aging

Age-related pathologies and conditions include atherosclerosis, hypertension, osteoporosis, obesity, insulin-resistance and type II diabetes, cancer, macular degeneration, Parkinson and Alzheimer's diseases as well as menopause in women, and many changes in the appearance that are not called diseases (baldness, for example) and presbyopia (a condition that resembles 
nearsightedness). Stroke, myocardial infarction, heart fibrillation, broken hip, renal and other organs failure are consequences of age-related pathology [17, 28, 31].

In brief, age-related diseases are both manifestations of advanced aging and causes of death. Aging is the sum of age-related diseases, syndromes and symptoms ranging from wrinkles and presbyopia to stroke and cancer metastasis. Of course, age-related diseases can occur in young patients with either genetic predisposition or due to environmental hazards. However, each of these diseases will develop in the aging organism, even without any predispositions and hazards, if the organism would live long enough. Since aging is not programmed, these diseases develop at different speeds. For example, menopause (in women) and presbyopia develop fast and strike all aging humans. Whereas, Alzheimer disease develops slowly and an elderly person can die from cancer or stroke before Alzheimer disease takes place [17, 28].

In brief, animals die from age-related diseases, which are manifestations of advanced aging (Figure 1). If a drug delays ALL age-related diseases, it is a classic antiaging drug because it will extend life span by delaying causes of death.

\section{What are (and are not) anti-aging drugs?}

Both insulin and metformin are used to treat type II diabetes. Insulin can save a patient in a diabetic coma. Metformin would not perform such a miracle. However, insulin cannot prevent diabetes, whereas metformin can. Insulin can also accelerate some diseases, whereas metformin decelerates them. (See metformin section for references). Insulin can foster cancer and obesity. Metformin prevents cancer and decreases obesity. Insulin activates the mTOR pathway, a key pathway of aging. Metformin indirectly inhibits the mTOR pathway. Insulin is a pro-aging drug, whereas metformin is an anti-aging drug.

\section{Criteria for potential anti-aging drugs}

1. A drug that prolongs life span in model organisms preferably in mammals.

2. A drug that prevents or delays several age-related diseases in mammals.

3. A drug that suppresses cellular geroconversion from quiescence to senescence

These criteria overlap each other. If an intervention extends life span, it must delay age-related diseases. Animals die from age-related diseases. For example, calorie restriction (CR) delays all diseases of aging and extends life span. One may say that CR extends life span by delaying diseases. One may say that CR delays diseases by slowing down aging. Both interpretations are correct. By the way, CR deactivates the nutrient-sensing pathway, known as TOR (Target of Rapamycin) [32]. According to all 3 criteria, rapamycin and other rapalogs are ultimate anti-aging drugs.

\section{Rapalogs: Rapamycin (Sirolimus/Rapamune) and Everalimus}

Rapalogs include rapamycin, known in the clinic as Sirolimus or Rapamune, everolimus, temsirolimus (a rapamycin prodrug) and deforolimus (Ridaforolimus). Rapalogs are prescription drugs taken by organ transplant recipients and cancer patients.

1. Rapamycin prolongs life span in mice [33-45] at doses that have no noticeable side effects [46-59].

2. Rapalogs prevent age-related diseases in mice as well as in other mammals including non-human primates and humans. As examples: rapamycin prevents atherosclerosis [60-64], neurodegeneration and retinopathy [65-67] and cardiopathy [68] in rodents. Rapalogs prevent cancer in mice and humans [34, 37, 38, 40, 41, 69-86]. Rapamycin decreases obesity in mice and humans [87-89]. As predicted [1], rapalogs rejuvenate immunity, improve immune response in aging mice [90] and humans [30, 91, 92]. Prevention of all age-related diseases by rapalogs was discussed in detail $[1,2,13,14,17,18,24,26,29,32$ 9395],

3. Rapalogs suppress cellular geroconversion from quiescence to senescence [20-23, 90, 96-110].

4. Rapamycin suppresses aging, age-related pathologies in model organisms:the yeast [111, 112], the fly [113-118] and the worm [119].

According to all criteria, rapalogs are anti-aging drugs. Importantly, rapalogs have minimal side effects, which can be reversed [120-122]. In some studies, rapamycin improves metabolic parameters [46, 49, 52, 56, 57, 88,123]. Rapalogs have been used in healthy volunteers [124, 125] and even in pregnant women without detrimental effects [126, 127]. Recently, rapamycin was investigated as an anti-aging drug in humans [128].

In transplant patients, rapalogs prevent cancer [6978]. This is a very good "side effect". In certain strains of mice, rapamycin causes symptoms of "hunger" pseudo-diabetes described 150 years ago by Claude Bernard [129]. "Hunger pseudo-diabetes" is not a disease. It is a beneficial condition during full fasting $[130,31]$. During starvation glucose must be spared for the brain, so the body becomes insulin-resistant and insulin production decreases. These metabolic changes are benevolent and therefore fasting is good for the health. In fact, rapamycin prevents complications of diabetes (nephropathy), while increasing glucose levels in genetically diabetic mice [131]. Prevention of diabetic complications with rapamycin has been discussed [31]. Unfortunately, basic scientists misinterpreted starvationlike effects of rapamycin as type 2 diabetes. Based on 
this misinterpretation, some gerontologists believe that this precludes the use of rapalogs in humans. Fortunately, rapalogs are already widely used in humans. In transplant patients, there is a very slight increase of diabetes manifestations in some studies but not in other studies $[132,133]$. Noteworthy, diabetes is common in transplant patients regardless of rapalog treatment, so this group of patients is not representative. What about healthy individuals? Acute administration of rapamycin reverses food-induced insulin resistance [134]. In other words, rapamycin increases insulin sensitivity in healthy people.

Of course, it is possible that chronic administration of rapamycin may cause beta-cell disfunction and diabetes in some genetically-predisposed humans, like it was observed in some mice strains [135]. This does not preclude the use of rapamycin as an anti-aging. Simply, glucose levels should be monitored and rapamycin can be discontinued, if glucose levels increase. Unlike transplant patients, healthy individuals can discontinue rapamycin at any time. And finally, to "mitigate" these worries, rapamycin can be combined with metformin.

\section{Metformin}

Metformin is one of the most commonly used drugs to treat type II diabetes. Before metformin, its analog phenformin - was used for type II diabetes. Phenformin was removed from the market because of the fear of its rare side effect: lactic acidosis. The incidence of lactic acidosis for metformin is lower than for phenformin.

Since 1972, Russian scientist, Vladimir Dilman, and his co-workers Anisimov, Bernstein and others, demonstrated that phenformin and metformin slow down aging, decrease obesity, prevent cancer and extend lifespan in rodents [136-146]. Furthermore, phenformin and metformin were administered to cancer patients [147]. For many years, these publications were ignored because it was believed that aging is driven by molecular damage and cannot be suppressed by anti-diabetic drugs. The antiaging effect of metformin and phenformin was explained by the hyper-function theory of aging [1].

In fact, metformin increases lifespan in mice [143] and C. elegans [148, 149]. Metformin prevents cancer and some other age-related diseases in humans. [150-161]. Furthermore, metformin decreases all-cause mortality in diabetic patients [156] and reduces the risk of cognitive decline and dementia [157]. Also, metformin is used to increase fertility $[162,163]$.

Thus, metformin (a) extends life span in worms and rodents and decreases all-cause mortality in humans (b) prevents several age-related diseases in rodents and humans. Yet, metformin did not increase lifespan in some model organisms. It does not increase lifespan in mice in some studies. The spectrum of metformin-responsive diseases is narrower than those for rapamycin. As a monotherapy, the life-extending effect of metformin may be modest, but it can be combined with rapamycin and other drugs.

Two agents may even cancel each other's potential side effects. For example, whereas metformin can increase lactate production, rapamycin decreases it [164]. This is important because phenformin was removed from the market because of the fear of lactate acidosis, caused by lactate production. On the other hand, metformin is expected to reduce manifestation of benevolent glucoseintolerance, if rapamycin will cause these manifestations, in a minority of individuals. A combination of rapamycin and metformin is also studied for cancer therapy [165, 166].

\section{Inhibitors of angiotensin II}

Angiotensin II receptor blockers (ARB) such as Valsartan, Telmisartan, Losartan and angiotensinconverting enzyme (ACE) inhibitors such as Captopril, Lisinopril, Enalapril, Ramipril are widely used to treat hypertension. Hypertension is a clear-cut disease of hyperfunction. Angiotensin II, a hormone, is involved in age-related diseases in mammals [167, 168]. Disruption of the angiotensin II receptor increases longevity in mice [169]. Variations of the angiotensin II receptor gene are associated with longevity in humans [170]. Inhibitors of angiotensin II double lifespan of hypertensive rats [171, 172]. This dramatic (100\%) increase is in part due to the anti-hypertensive effect. Yet, in healthy (those with normal blood pressure) rats, long-term treatment with enalapril decreases weight and prolongs life span dramatically [173]. In humans, inhibitors of angiotensin II prevent cardiac hypertrophy and organ fibrosis [168], [174], a hallmark of aging. In some studies, long-term use of ARBs was associated with a lower incidence of cancer [175]. Enalapril and perindopril did not decrease blood pressure in patients with normal blood pressure [176]. Importantly, angiotensin-converting enzyme inhibitors or angiotensin receptor blockers are beneficial in normotensive atherosclerotic patients [177].

\section{Aspirin}

Aspirin or acetylsalicylic acid, an inhibitor of cyclooxygenase (COX), is one of the most widely used non-prescription drugs. Aspirin inhibits inflammation. Proinflammation (an example of hyperfunction) is a hallmark of aging [178, 179]. Aspirin also inhibits hyper-functional platelets, preventing thrombosis and atherosclerosis. Inhibition of hyper-active platelets prevents cardiovascular diseases and cancer [180].

Aspirin prolongs life span in Drosophila [181], C elegans [182, 183] and mice [184]. Aspirin reverses glucose intolerance in rats [185]. Anti-aging activities of aspirin have been discussed [105, 186,187]. 
Aspirin is used to prevent age-related diseases including cardiovascular diseases and cancer in humans. Numerous studies have demonstrated benefits, although doses and duration of treatment remain uncertain. For example, $600 \mathrm{mg}$ aspirin per day for 25 months decreased the incidence of cancer in carriers of hereditary colorectal cancer [188]. In another study, $300 \mathrm{mg}$ a day for 5 years prevented colorectal cancer [189]. Long-term daily use of aspirin decreases the incidence of colorectal, prostate, and breast cancers [190]. In some studies, regular, longterm aspirin use reduced the risk of colorectal cancer [191], whereas, in other studies, occasional use of aspirin prevented vascular diseases and cancer [192]. In one of the most comprehensive studies, aspirin at doses between 75 and $325 \mathrm{mg} /$ day for 5 years significantly decreased cancer incidence [192]. It slightly increased chances of gastric bleeding [192, 193]. It was estimated that, by preventing cancer, aspirin can save more lives than lost lives due to potential side effects [192. 193].

\section{Statins}

Statins, such as atorvastatin (Lipitor), simvastatin and lovastatin, decrease blood cholesterol levels and thus decelerate atherosclerosis, preventing cardiovascular diseases [194]. Statins are beneficial in hypertension [195197]. Statins can decrease the incidence of some cancers
[198]. Simvastatin increases mean and maximum lifespan of Drosophila [199]. Statins increase life span in progeroid mice [200]. Yet, in another study, a statin did not prolong life span in mice [36]. Statins prolong lifespan by 2 years in humans treated at ages 78 to 85 [194]. Among the very old, the extension of life was independent of cholesterol levels [201].

Noteworthy, statins can prevent rapamycin-induced dyslipidemia [202]. This benevolent dyslipidemia is caused by lipolysis and inhibition of lipoproteins uptake by the tissues (see Figure 2 in [94]). Dyslipidemia is reversible by itself [64]. Yet, it is easier to combine rapamycin and statins than to prove that dyslipidemia is totally harmless. Statins can "mitigate the fear" of this rapamycin-induced "side effect". Statins have side-effects, which are, in rare cases, dangerous. Statins, which are prescription drugs, are available in grocery stores without prescription as natural products. Lovastatin is a natural compound found in oyster mushrooms and red yeast rice, a food supplement. Red yeast rice is often combined with berberine and policosanol, natural food supplements.

\section{Beta-blockers}

Beta-blockers are widely used to treat hypertension and heart diseases. Propranolol, a non-selective betaadrenergic blocker, prevents cancer [203-206] and

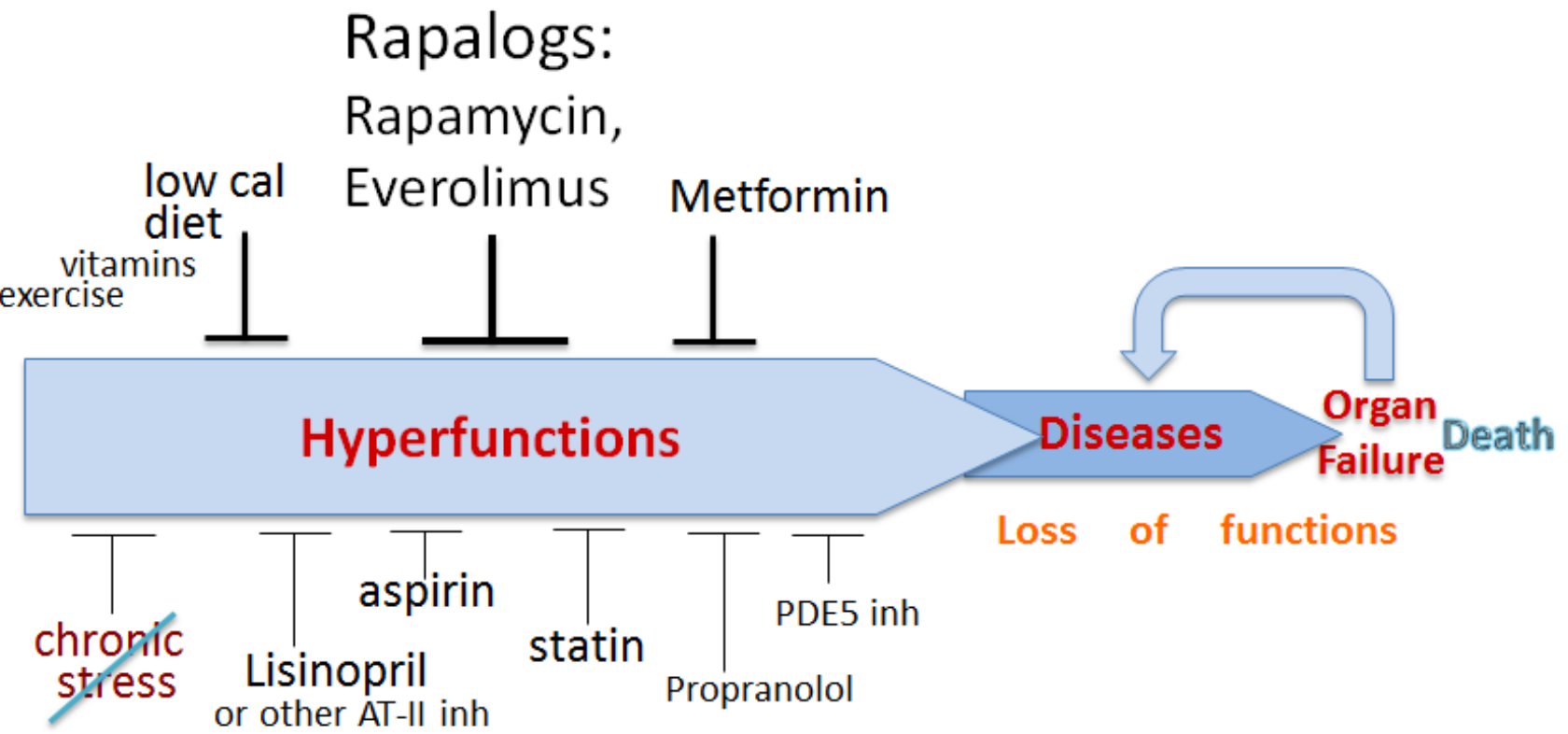

Figure 1: Schema of aging and its pharmacological suppression. Aging is an increase in the probability of death. Aging is a continuation of developmental growth, when the development is stopped but signaling pathways (such as mTOR) remain active. Chronic cellular overactivation increases cellular functions (secretion, synthesis, metabolism, contraction, aggregation, lipid accumulation and so on), leading to systemic hyperfuntions such as hypertension and other diseases of aging. Hyperfunction, manifested as age-related diseases, causes organ damage and loss of functions. Aging consists from subclinical hyperfunction, diseases and loss of function/organ failure. Anti-aging drugs inhibit signaling pathways, decreasing hyperfunction, slowing down aging and delaying diseases and death. The most important drugs are shown in larger fonts. 
hepatic steatosis [207]. Propranolol is used out-of-label to decrease anxiety. Metoprolol and nebivolol increase the mean and median life span of male mice, by $10 \%$ and 6.4\% and extend Drosophila life span [208].

\section{PDE5 inhibitors}

Phosphodiesterase 5 (PDE5) degrades cGMP. PDE5 inhibitors, including sildenafil (Viagra), tadalafil (Cialis), vardenafil (Levitra), and avanafil (Stendra), are widely known for treatment of erectile dysfunction (ED). While sexual stimulation causes cGMP synthesis, PDE5 inhibitors cause its accumulation, relaxing corpus cavernosum and penile arteries. In addition, cGMP relaxes the tone of prostate muscle cells and decreases prostate inflammation. Tadalafil is effective and well-tolerated therapy for benign prostate hyperplasia (BPH) [209]. PDE5 inhibitors, such as long-acting tadalafil, can be added to anti-aging drug mixture because ED and BPH are most prevalent age-related conditions in aging men. Also, there is a fundamental reason to consider PDE5 inhibitors as anti-aging medicines (in both men and women). The key word is "relax". Senescent cells are tense and stressed. Cellular senescence is manifested by hyper-function. On the organism levels hyper-function is translated in hypertension, hyperplasia, hyperlipidemia and so on. By 'relaxing the tension', PDE5 inhibitors may slow senescent-associated pathology. PFE5 inhibitors cause anti-vasoconstriction, anti-proliferative and antiinflammatory effects. Not co-incidentally, PDE5 inhibitors are already approved or investigated for therapy of diverse age-related diseases and conditions. Sildenafil and tadalafil are approved for pulmonary arterial hypertension [210]. PDE5 inhibitors are under investigation for heart hypertrophy, myocardial infarction, cancer, neurodegenerative diseases, cystic fibrosis, diabetes, obesity and metabolic syndrome [210-213]. Inhibition of PDE5 increases levels of cGMP and hydrogen sulfate. These signaling molecules increase life span in $\mathrm{C}$ elegans [214, 215].

PDE5 inhibitors are remarkably safe for everyday use for a long term. In most studies, $5 \mathrm{mg}$ tadalafil once a day had minimal side effect and improved BPH and ED [216]. Furthermore, even $40 \mathrm{mg}$ of tadalafil is used in the treatment of pulmonary arterial hypertension without serious side effects [217]. PDE5 inhibition improves betacell function in metabolic syndrome [218, 219]. This may mitigate potential side effect of rapamycin on beta-cells.

\section{Doxocycline}

Doxocycline, broad-spectrum antibiotics of the tetracycline class, extends life span in C elegans [220] and Drosophila [221, 222]. Doxycycline suppresses tumor growth and metastasis in mice [223, 224]. Importantly, doxycycline is a component of an anti-metastatic combination, which includes doxycyclin, aspirin, lisin and mifepristone [225].

\section{Melatonin}

Melatonin, a hormone, which is sold as a nonprescription sleeping pill, increases life span and decreases cancer incidence in animals in some studies [226]-229]. Yet, other studies were inconclusive.

\section{Experimental gerosuppressants}

Like rapalogs, pan-mTOR inhibitors suppress geroconversion $[107-109,110,230]$. They suppress geroconversion at concentrations lower than anti-cancer doses [230]. Low doses of pan-mTOR inhibitors have not been yet tested in mice to determine the effect of life span. Since these drugs are not yet approved for human use, we will not discuss them here. MDM-2 inhibitors [96, 231] MEK inhibitors [232] and S6K inhibitors [233] also suppress geroconversion in cell type-specific manner. Gerosuppression and tumor-suppression are two sides of one coin, so not surprisingly, they were intended as anticancer drugs [234-236]. At anti-cancer doses, gerosuppressants inhibit cell proliferation. Therefore, anti-aging doses should be lower than standard anticancer doses. Alternatively, gerosuppressants should be used intermittently: high therapeutic doses followed by treatment-free periods.

\section{Polypill}

Polypill is a fixed-dose combination of antiplatelet (aspirin), anti-hypertensive drugs (lisinopril and betablocker), and a statin [237-239]. Polypill also may include additional anti-hypertensive drugs [240] as well as folic acid [237]. Polypill showed life-extending activity in highrisk elderly individuals [241, 242]. It was calculated that polypill may reduce strokes and ischemic heart disease by over $80 \%$ in individuals at risk for cardiovascular diseases [242]. Polypill may prevent cardiovascular disease and strokes [243, 244]. Polypill includes 4 'anti-aging' drugs (statin, aspirin, beta-blocker, angiotensin II inhibitor such as lisinopril). Yet, this combination was created to prevent cardiovascular diseases, not to slow aging. Therefore, Polypill does not include two main anti-aging components: a rapalog and metformin. Nevertheless, Polypill is used in 'healthy' aging humans in order to extend life span by preventing diseases. It needs to be combined with rapamycin and metformin, to maximize lifespan extension. 


\section{Anti-aging combinations}

Rapamycin (or another rapalog) should be a cornerstone of anti-aging combinations (Figure 1), given its universal anti-aging effect and the ability to delay almost all diseases of aging.

Rapamycin and metformin: Both drugs extend lifespan in animals and have non- overlapping effects. In addition, they may, in theory, cancel possible metabolic side-effects of each other. As we discussed here (see rapamycin section) as well as in $[31,130]$, rapamycin in different settings may either increase or decrease insulin sensitivity. Similarly, calorie restriction increases insulin sensitivity, whereas severe calorie restriction (starvation) decreases it [129, 245]. In any case, rapamycin prolongs life span, indicating that insulin resistance is benevolent [130]. Unfortunately, the fear of this benevolent 'side effect' is delaying applications of rapamycin for prevention of age-related diseases. The simplest approach is to monitor glucose levels in individuals taking rapamycin. In addition, metformin, an anti-diabetic drug that reverses insulin resistance, could be combined with rapamycin.

And vice verse, metformin may potentially increase blood lactate levels. Rapamycin decreases lactate production [164]. Each drug prolongs lifespan in mice, prevents cancer, atherosclerosis, and other diseases of aging.

Rapamycin and statins: Rapamycin promotes lipolysis increasing blood levels of fatty acids. This, in turn, increases levels of lipoproteins produced by the liver. Rapamycin-induced hyperlipidemia is benevolent and reversible. Still, statins are already used to prevent rapamycin-induced hyperlipidemia [202, 246, 247]

Rapamycin and physical exercise: Similarly, physical exercise may be useful to prevent rapamycininduced hyperlipidemia because fatty acids are used by the muscle during physical exercise.

\section{Rapamycin and low-calorie diet or intermittent fasting:}

a. During fasting, the organism depends on lipolysis and ketogenesis. Rapamycin stimulates these processes. Fatty acids and ketone bodies will be used by the muscle and the brain, respectively.

b. Fasting decreases glucose, potentially mitigating possible rapamycin-induced hyperglycemia

The effects of rapamycin and calorie-restriction are not identical and may be additive [248, 249]. Calorie restriction and intermittent fasting extend life span. A low-calorie diet can be supplemented with vitamins (poly-vitamins plus, B3, B12 and D3), minerals and even essential amino and fatty acids, if needed, to avoid malnutrition.

It is commonly suggested that certain food is beneficial because it is rich in some 'useful' ingredients: anti-oxidants, vitamins, minerals, essential fatty acids. Yet, food is also rich in calories. Using supplements, there is no need to eat food because it is "rich in something" (vitamin C, D or promega-3). Eating food for any essential component will bring calories along with the essential component. Food rich in vitamins could be substituted with vitamins alone.

\section{Rapamycin and PDE5 inhibitors}

Cialis is approved for treatment of BPH and rapamycin treat $\mathrm{BPH}$ in preclinical studies. Rapamycin can decrease beta-cell function, whereas PDE5 inhibitors can increase it.

\section{Rapamycin-based mixtures:}

A. Rapamycin plus metformin (especially in insulinresistant and obese people, metformin is indicated).

B. Rapamycin plus Lisinopril (or other angiotensin II-inhibitor) plus propranolol. Like in Polypill, these prescription drugs may be used at $1 / 2$ doses in normotensive individuals. Hypertensive patients may require full doses.

C. Rapamycin plus Statin (such as lovastatin, simvastatin and atorvastatin)

D. Rapamycin plus Statin plus metformin. This combination with rapamycin may be the most attractive for people with metabolic alterations: hyperlipidemia, obesity, insulin resistance.

E. Rapamycin plus polypill-like combination (Lisinopril, propranolol, aspirin, statin). This is especially attractive in people with atherosclerosis given that rapamycin prevents atherosclerosis too.

F. Rapamycin plus Lisinopril (or other Angiotensin II-inhibitor) + propranolol + aspirin + statin + metformin + PDE5inhibitor. This is a comprehensive 7-drug combination.

\section{Doses and schedules}

In the 7-drug anti-aging combination, rapamycin, metformin, lisinopril (or its equivalent), a statin, a PDE5 inhibitor and propranolol are prescription drugs (in the USA). So I will not discuss doses and schedules here. They should be determined for each individual individually. Polypill composition provides the hint on doses of 4 drugs in healthy individuals. The doses of rapamycin are beyond the scope of this article. Mixtures of anti-aging drugs should be further complemented with physical exercise and low-calorie diet or intermittent diet. Additional drugs such as melatonin may be considered. The 7-drug combination can be tested in mice, especially in mice on high fat diet and in cancer-prone mice. If started late in life, the experiments will take just several months to evaluate the effect on lifespan and cancer incidence as well as weight, blood pressure, glucose, insulin, triglycerides 
and leptin. In humans, the treatment program can be initiated regardless of any pre-clinical studies, because all 7 drugs are approved for human use and some of them such as aspirin and statin are widely used for disease prevention anyway. The only what is needed is to watch for side effects. Especially, heart rate, blood pressure and glucose levels should be monitored.

\section{From past to the future}

As stated in 2006, “... rapamycin, is already approved for clinical use, available and can be used immediately ... to slow down senescence and to prevent diseases."[1]. It was suggested that in intermittent schedules, rapamycin will be effective, yet lack side effects. Pulse-treatment was suggested to improve wound healing and rejuvenate stem cells and immunity [1, 27]. After 10 years, this suggestion remains unchanged. The implementation of anti-aging drugs to live longer and to delay age-related diseases was discussed in detail [94, 250, 251].

Now, the time is for the anti-aging formula, which combines around 7 drugs with diet and physical exercise. The anti-aging formula is ready for human use. If one will wait until the life-extending effect will be shown in others, this individual will not be alive by the time of the result. Human clinical trials are needed to optimize the doses and schedules. However, unless we participate in clinical trials ourselves, we will not know how long participants will live because they are expected to outlive non-participants. If we want to live longer we should be participants in clinical trials. In the best scenario, this might allow us to live long enough to benefit from future discoveries of anti-aging remedies. Experimental anti-aging drugs such as pan-mTOR inhibitors might be approved for future anti-aging formulas. Finally, if mTOR-driven aging will be abolished, anti-oxidants may become useful to treat post-aging syndrome [245]. And step-by-step, humanity will extend life span.

\section{CONFLICTS OF INTEREST}

The author have no relevant conflicts of interest to disclose.

\section{REFERENCES}

1. Blagosklonny MV. Aging and immortality: quasiprogrammed senescence and its pharmacologic inhibition. Cell Cycle. 2006; 5: 2087-2102.

2. Blagosklonny MV. Aging: ROS or TOR. Cell Cycle. 2008; 7: 3344-3354.

3. Howes RM. The free radical fantasy: a panoply of paradoxes. Ann N Y Acad Sci. 2006; 1067: 22-26.

4. Bjelakovic G, Nikolova D, Gluud LL, Simonetti RG, Gluud
C. Mortality in randomized trials of antioxidant supplements for primary and secondary prevention: systematic review and meta-analysis. JAMA. 2007; 297: 842-857.

5. Bjelakovic G, Nikolova D, Gluud LL, Simonetti RG, Gluud C. Antioxidant supplements for prevention of mortality in healthy participants and patients with various diseases. Cochrane Database Syst Rev. 2012; 3: CD007176.

6. Bjelakovic G, Nikolova D, Gluud C. Meta-regression analyses, meta-analyses, and trial sequential analyses of the effects of supplementation with beta-carotene, vitamin A, and vitamin $\mathrm{E}$ singly or in different combinations on allcause mortality: do we have evidence for lack of harm? PLoS One. 2013; 8: e74558.

7. Chong EW, Wong TY, Kreis AJ, Simpson JA, Guymer RH. Dietary antioxidants and primary prevention of age related macular degeneration: systematic review and meta-analysis. BMJ. 2007; 335: 755.

8. Myung SK, Ju W, Cho B, Oh SW, Park SM, Koo BK, Park BJ. Efficacy of vitamin and antioxidant supplements in prevention of cardiovascular disease: systematic review and meta-analysis of randomised controlled trials. Bmj. 2013; 346: f10.

9. Ristow M, Zarse K, Oberbach A, Kloting N, Birringer M, Kiehntopf M, Stumvoll M, Kahn CR, Bluher M. Antioxidants prevent health-promoting effects of physical exercise in humans. Proc Natl Acad Sci U S A. 2009; 106: 8665-8670.

10. Lapointe J, Hekimi S. When a theory of aging ages badly. Cell Mol Life Sci. 2009; 67: 1-8.

11. Andziak B, O'Connor TP, Buffenstein R. Antioxidants do not explain the disparate longevity between mice and the longest-living rodent, the naked mole-rat. Mech Ageing Dev. 2005; 126: 1206-1212.

12. Schulz TJ, Zarse K, Voigt A, Urban N, Birringer M, Ristow M. Glucose restriction extends Caenorhabditis elegans life span by inducing mitochondrial respiration and increasing oxidative stress. Cell Metab. 2007; 6: 280-293.

13. Gems D, Partridge L. Genetics of Longevity in Model Organisms: Debates and Paradigm Shifts. Annu Rev Physiol. 2013; 75: 621-644.

14. Gems DH, de la Guardia YI. Alternative Perspectives on Aging in C. elegans: Reactive Oxygen Species or Hyperfunction? Antioxid Redox Signal. 2013; 19: 321-329.

15. Blagosklonny MV. mTOR-driven aging: speeding car without brakes. Cell Cycle. 2009; 8: 4055-4059.

16. Blagosklonny MV. Hormesis does not make sense except in the light of TOR-driven aging. Aging (Albany NY). 2011; 3: 1051-1062. doi: 10.18632/aging.100411.

17. Blagosklonny MV. Answering the ultimate question "what is the proximal cause of aging?" Aging (Albany NY). 2012; 4: 861-877. doi: 10.18632/aging.100525.

18. Stipp D. A new path to longevity. Sci Am. 2012; 306: 3239.

19. Blagosklonny MV. Cell senescence and hypermitogenic 
arrest. EMBO Rep. 2003; 4: 358-362.

20. Blagosklonny MV. Cell cycle arrest is not yet senescence, which is not just cell cycle arrest: terminology for TORdriven aging. Aging (Albany NY). 2012; 4: 159-165. doi: 10.18632/aging.100443.

21. Blagosklonny MV. Geroconversion: irreversible step to cellular senescence. Cell Cycle. 2014; 13:3628-35.

22. Sousa-Victor $\mathrm{P}$, Perdiguero E, Munoz-Canoves $\mathrm{P}$. Geroconversion of aged muscle stem cells under regenerative pressure. Cell Cycle. 2014; 13: 3183-3190.

23. Demidenko ZN, Blagosklonny MV. Growth stimulation leads to cellular senescence when the cell cycle is blocked. Cell Cycle. 2008; 7 : 3355-3361.

24. Blagosklonny MV, Hall MN. Growth and aging: a common molecular mechanism. Aging (Albany NY). 2009; 1: 357 362. doi: 10.18632/aging.100040.

25. Blagosklonny MV. MTOR-driven quasi-programmed aging as a disposable soma theory: blind watchmaker vs. intelligent designer. Cell Cycle. 2013; 12: 1842-1847.

26. Blagosklonny MV. Aging is not programmed: Genetic pseudo-program is a shadow of developmental growth. Cell Cycle. 2013; 12: 3736-3742.

27. Blagosklonny MV. An anti-aging drug today: from senescence-promoting genes to anti-aging pill. Drug Disc Today. 2007; 12: 218-224.

28. Blagosklonny MV. Prospective treatment of age-related diseases by slowing down aging. Am J Pathol. 2012; 181: 1142-1146.

29. Blagosklonny MV. Rapamycin and quasi-programmed aging: Four years later. Cell Cycle. 2010; 9: 1859-1862.

30. Blagosklonny MV. Rejuvenating immunity: "anti-aging drug today" eight years later. Oncotarget. 2015; 6: 19405 19412. doi: 10.18632/oncotarget.3740.

31. Blagosklonny MV. TOR-centric view on insulin resistance and diabetic complications: perspective for endocrinologists and gerontologists. Cell Death Dis. 2013; 4: e964.

32. Blagosklonny MV. Calorie restriction: Decelerating mTORdriven aging from cells to organisms (including humans). Cell Cycle. 2010; 9: 683-688.

33. Harrison DE, Strong R, Sharp ZD, Nelson JF, Astle CM, Flurkey K, Nadon NL, Wilkinson JE, Frenkel K, Carter CS, Pahor M, Javors MA, Fernandezr E, Miller RA. Rapamycin fed late in life extends lifespan in genetically heterogenous mice. Nature. 2009; 460: 392-396.

34. Anisimov VN, Zabezhinski MA, Popovich IG, Piskunova TS, Semenchenko AV, Tyndyk ML, Yurova MN, Antoch MP, Blagosklonny MV. Rapamycin extends maximal lifespan in cancer-prone mice. Am J Pathol. 2010; 176: 2092-2097.

35. Anisimov VN, Zabezhinski MA, Popovich IG, Piskunova TS, Semenchenko AV, Tyndyk ML, Yurova MN, Rosenfeld SV, Blagosklonny MV. Rapamycin increases lifespan and inhibits spontaneous tumorigenesis in inbred female mice. Cell Cycle. 2011; 10: 4230-4236.
36. Miller RA, Harrison DE, Astle CM, Baur JA, Boyd AR, de Cabo R, Fernandez E, Flurkey K, Javors MA, Nelson JF, Orihuela CJ, Pletcher S, Sharp ZD, et al. Rapamycin, but not resveratrol or simvastatin, extends life span of genetically heterogeneous mice. J Gerontol A Biol Sci Med Sci. 2011; 66: 191-201.

37. Komarova EA, Antoch MP, Novototskaya LR, Chernova OB, Paszkiewicz G, Leontieva OV, Blagosklonny MV, Gudkov AV. Rapamycin extends lifespan and delays tumorigenesis in heterozygous p53+/- mice. Aging (Albany NY). 2012; 4: 709-714. doi: 10.18632/aging.100498.

38. Comas M, Toshkov I, Kuropatwinski KK, Chernova OB, Polinsky A, Blagosklonny MV, Gudkov AV, Antoch MP. New nanoformulation of rapamycin Rapatar extends lifespan in homozygous p53-/- mice by delaying carcinogenesis. Aging (Albany NY). 2012; 4: 715-722. doi: 10.18632/aging.100496.

39. Ramos FJ, Chen SC, Garelick MG, Dai DF, Liao CY, Schreiber KH, MacKay VL, An EH, Strong R, Ladiges WC, Rabinovitch PS, Kaeberlein M, Kennedy BK. Rapamycin reverses elevated mTORC1 signaling in lamin A/C-deficient mice, rescues cardiac and skeletal muscle function, and extends survival. Sci Transl Med. 2012; 4: 144ra103.

40. Livi CB, Hardman RL, Christy BA, Dodds SG, Jones D, Williams C, Strong R, Bokov A, Javors MA, Ikeno Y, Hubbard G, Hasty P, Sharp ZD. Rapamycin extends life span of Rb1+/- mice by inhibiting neuroendocrine tumors. Aging (Albany NY). 2013; 5: 100-110. doi: 10.18632/ aging. 100533 .

41. Popovich IG, Anisimov VN, Zabezhinski MA, Semenchenko AV, Tyndyk ML, Yurova MN, Blagosklonny MV. Lifespan extension and cancer prevention in HER-2/ neu transgenic mice treated with low intermittent doses of rapamycin. Cancer Biol Ther. 2014; 15: 586-592.

42. Johnson SC, Yanos ME, Kayser EB, Quintana A, Sangesland M, Castanza A, Uhde L, Hui J, Wall VZ, Gagnidze A, Oh K, Wasko BM, Ramos FJ, et al. mTOR inhibition alleviates mitochondrial disease in a mouse model of Leigh syndrome. Science. 2013; 342: 1524-1528.

43. Fok WC, Chen Y, Bokov A, Zhang Y, Salmon AB, Diaz V, Javors M, Wood WH 3rd, Becker KG, Perez VI, Richardson A. Mice fed rapamycin have an increase in lifespan associated with major changes in the liver transcriptome. PLoS One. 2013; 9: e83988.

44. Bitto A, Ito TK, Pineda VV, LeTexier NJ, Huang HZ, Sutlief E, Tung H, Vizzini N, Chen B, Smith K, Meza D, Yajima M, Beyer RP, et al. Transient rapamycin treatment can increase lifespan and healthspan in middle-aged mice. Elife. 2016; 5. e16351.

45. Johnson SC, Kaeberlein M. Rapamycin in aging and disease: maximizing efficacy while minimizing side effects. Oncotarget. 2016; 7: 44876-44878. doi: 10.18632/ oncotarget.10381.

46. Fang Y, Bartke A. Prolonged rapamycin treatment led to 
beneficial metabolic switch. Aging (Albany NY). 2013; 5: 328-329. doi: 10.18632/aging.100554.

47. Ye L, Widlund AL, Sims CA, Lamming DW, Guan Y, Davis JG, Sabatini DM, Harrison DE, Vang O, Baur JA. Rapamycin doses sufficient to extend lifespan do not compromise muscle mitochondrial content or endurance. Aging (Albany NY). 2013; 5: 539-550. doi: 10.18632/ aging. 100576.

48. Zhang XM, Li L, Xu JJ, Wang N, Liu WJ, Lin XH, Fu YC, Luo LL. Rapamycin preserves the follicle pool reserve and prolongs the ovarian lifespan of female rats via modulating mTOR activation and sirtuin expression. Gene. 2013; 523: $82-87$.

49. Zhang Y, Bokov A, Gelfond J, Soto V, Ikeno Y, Hubbard G, Diaz V, Sloane L, Maslin K, Treaster S, Rendon S, van Remmen H, Ward W, et al. Rapamycin extends life and health in C57BL/6 mice. J Gerontol A Biol Sci Med Sci. 2014; 69: 119-130.

50. Flynn JM, O'Leary MN, Zambataro CA, Academia EC, Presley MP, Garrett BJ, Zykovich A, Mooney SD, Strong R, Rosen CJ, Kapahi P, Nelson MD, Kennedy BK, Melov $\mathrm{S}$. Late life rapamycin treatment reverses age-related heart dysfunction. Aging Cell. 2013; 12: 851-862.

51. Luo LL, Xu JJ, Fu YC. Rapamycin prolongs female reproductive lifespan. Cell Cycle. 2013; 12: 3353-3354.

52. Leontieva OV, Paszkiewicz GM, Blagosklonny MV. Weekly administration of rapamycin improves survival and biomarkers in obese male mice on high-fat diet. Aging Cell. 2014; 616-622.

53. Fischer KE, Gelfond JA, Soto VY, Han C, Someya S, Richardson A, Austad SN. Health Effects of Long-Term Rapamycin Treatment: The Impact on Mouse Health of Enteric Rapamycin Treatment from Four Months of Age throughout Life. PLoS One. 10: e0126644.

54. Xue QL, Yang H, Li HF, Abadir PM, Burks TN, Koch LG, Britton SL, Carlson J, Chen L, Walston JD, Leng SX. Rapamycin increases grip strength and attenuates agerelated decline in maximal running distance in old low capacity runner rats. Aging (Albany NY). 2016; 8: 769-776. doi: 10.18632/aging.100929.

55. Liu Y, Diaz V, Fernandez E, Strong R, Ye L, Baur JA, Lamming DW, Richardson A, Salmon AB. Rapamycininduced metabolic defects are reversible in both lean and obese mice. Aging (Albany NY). 2014; 6: 742-754. doi: 10.18632/aging.100688.

56. Leontieva OV, Paszkiewicz G, Demidenko ZN, Blagosklonny MV. Resveratrol potentiates rapamycin to prevent hyperinsulinemia and obesity in male mice on high fat diet. Cell Death Dis. 2013; 4: e472.

57. Leontieva OV, Paszkiewicz GM, Blagosklonny MV. Comparison of rapamycin schedules in mice on high-fat diet. Cell Cycle. 2014; 13: 3350-3356.

58. Kondratov RV, Kondratova AA. Rapamycin in preventive (very low) doses. Aging (Albany NY). 2014; 6: 158-159. doi: 10.18632/aging.100645.

59. Khapre RV, Kondratova AA, Patel S, Dubrovsky Y, Wrobel M, Antoch MP, Kondratov RV. BMAL1-dependent regulation of the $\mathrm{mTOR}$ signaling pathway delays aging. Aging (Albany NY). 2014; 6: 48-57. doi: 10.18632/ aging.100633.

60. Guarda E, Marchant E, Fajuri A, Martinez A, Moran S, Mendez M, Uriarte P, Valenzuela E, Lazen R. Oral rapamycin to prevent human coronary stent restenosis: a pilot study. Am Heart J. 2004; 148: e9.

61. Shioi T, McMullen JR, Tarnavski O, Converso K, Sherwood MC, Manning WJ, Izumo S. Rapamycin attenuates loadinduced cardiac hypertrophy in mice. Circulation. 2003; 107: 1664-1670.

62. Waksman R, Pakala R, Burnett MS, Gulick CP, Leborgne L, Fournadjiev J, Wolfram R, Hellinga D. Oral rapamycin inhibits growth of atherosclerotic plaque in apoE knock-out mice. Cardiovasc Radiat Med. 2003; 4: 34-38.

63. Pakala R, Stabile E, Jang GJ, Clavijo L, Waksman R. Rapamycin attenuates atherosclerotic plaque progression in apolipoprotein E knockout mice: inhibitory effect on monocyte chemotaxis. J Cardiovasc Pharmacol. 2005; 46: 481-486.

64. Chen WQ, Zhong L, Zhang L, Ji XP, Zhang M, Zhao YX, Zhang C, Zhang Y. Oral rapamycin attenuates inflammation and enhances stability of atherosclerotic plaques in rabbits independent of serum lipid levels. Br J Pharmacol. 2009; 156: 941-951.

65. Sarkar S, Ravikumar B, Floto RA, Rubinsztein DC. Rapamycin and mTOR-independent autophagy inducers ameliorate toxicity of polyglutamine-expanded huntingtin and related proteinopathies. Cell Death Differ. 2009; 16: 46-56.

66. Kolosova NG, Vitovtov AO, Muraleva NA, Akulov AE, Stefanova NA, Blagosklonny MV. Rapamycin suppresses brain aging in senescence-accelerated OXYS rats. Aging (Albany NY). 2013; 5: 474-484. doi: 10.18632/ aging. 100573 .

67. Kolosova NG, Muraleva NA, Zhdankina AA, Stefanova NA, Fursova AZ, Blagosklonny MV. Prevention of agerelated macular degeneration-like retinopathy by rapamycin in rats. Am J Pathol. 2012; 181: 472-477.

68. Chiao YA, Kolwicz SC, Basisty N, Gagnidze A, Zhang J, Gu H, Djukovic D, Beyer RP, Raftery D, MacCoss M, Tian R, Rabinovitch PS. Rapamycin transiently induces mitochondrial remodeling to reprogram energy metabolism in old hearts. Aging (Albany NY). 2016; 8: 314-327. doi: 10.18632/aging. 100881 .

69. Granville CA, Warfel N, Tsurutani J, Hollander MC, Robertson M, Fox SD, Veenstra TD, Issaq HJ, Linnoila RI, Dennis PA. Identification of a highly effective rapamycin schedule that markedly reduces the size, multiplicity, and phenotypic progression of tobacco carcinogen-induced murine lung tumors. Clin Cancer Res. 2007; 13: 2281-2289. 
70. Kauffman HM, Cherikh WS, Cheng Y, Hanto DW, Kahan BD. Maintenance immunosuppression with target-ofrapamycin inhibitors is associated with a reduced incidence of de novo malignancies. Transplantation. 2005; 80: 883889.

71. Cullis B, D'Souza R, McCullagh P, Harries S, Nicholls A, Lee R, Bingham C. Sirolimus-induced remission of posttransplantation lymphoproliferative disorder. Am J Kidney Dis. 2006; 47: e67-72.

72. Law BK. Rapamycin: an anti-cancer immunosuppressant? Crit Rev Oncol Hematol. 2005; 56: 47-60.

73. Campistol JM, Eris J, Oberbauer R, Friend P, Hutchison B, Morales JM, Claesson K, Stallone G, Russ G, Rostaing L, Kreis H, Burke JT, Brault Y, et al. Sirolimus Therapy after Early Cyclosporine Withdrawal Reduces the Risk for Cancer in Adult Renal Transplantation. J Am Soc Nephrol. 2006; 17: 581-589.

74. Stallone G, Schena A, Infante B, Di Paolo S, Loverre A, Maggio G, Ranieri E, Gesualdo L, Schena FP, Grandaliano G. Sirolimus for Kaposi's sarcoma in renal-transplant recipients. N Engl J Med. 2005; 352: 1317-1323.

75. Knoll GA, Kokolo MB, Mallick R, Beck A, Buenaventura CD, Ducharme R, Barsoum R, Bernasconi C, Blydt-Hansen TD, Ekberg H, Felipe CR, Firth J, Gallon L, et al. Effect of sirolimus on malignancy and survival after kidney transplantation: systematic review and meta-analysis of individual patient data. Bmj. 2014; 349: g6679.

76. Fernandez A, Hu S, Kirsner RS. Sirolimus: a potential chemopreventive agent. J Invest Dermatol. 2008; 128: 2352.

77. Blagosklonny MV. Prevention of cancer by inhibiting aging. Cancer Biol Ther. 2008; 7: 1520-1524.

78. Blagosklonny MV. Rapalogs in cancer prevention: Antiaging or anticancer? Cancer Biol Ther. 2012; 13: 13491354.

79. de Gruijl FR, Koehl GE, Voskamp P, Strik A, Rebel HG, Gaumann A, de Fijter JW, Tensen CP, Bavinck JN, Geissler EK. Early and late effects of the immunosuppressants rapamycin and mycophenolate mofetil on UV carcinogenesis. Int J Cancer. 2010; 127: 796-804.

80. Halleck F, Budde K. Transplantation: Sirolimus for secondary SCC prevention in renal transplantation. Nat Rev Nephrol. 2012; 8: 687-689.

81. Alberu J, Pascoe MD, Campistol JM, Schena FP, Rial Mdel C, Polinsky M, Neylan JF, Korth-Bradley J, Goldberg-Alberts R, Maller ES. Lower malignancy rates in renal allograft recipients converted to sirolimus-based, calcineurin inhibitor-free immunotherapy: 24-month results from the CONVERT trial. Transplantation. 2011; 92: 303310 .

82. Euvrard S, Morelon E, Rostaing L, Goffin E, Brocard A, Tromme I, Broeders N, del Marmol V, Chatelet V, Dompmartin A, Kessler M, Serra AL, Hofbauer GF, et al. Sirolimus and secondary skin-cancer prevention in kidney transplantation. N Engl J Med. 2012; 367: 329-339.

83. Alter M, Satzger I, Schrem H, Kaltenborn A, Kapp A, Gutzmer R. Non-melanoma skin cancer is reduced after switch of immunosuppression to mTOR-inhibitors in organ transplant recipients. J Dtsch Dermatol Ges. 2014; 12: 480488.

84. Karia PS, Azzi JR, Heher EC, Hills VM, Schmults CD. Association of Sirolimus Use With Risk for Skin Cancer in a Mixed-Organ Cohort of Solid-Organ Transplant Recipients With a History of Cancer. JAMA Dermatol. 2016; 152: 533-540.

85. Donehower LA. Rapamycin as longevity enhancer and cancer preventative agent in the context of p53 deficiency. Aging (Albany NY). 2012; 4: 660-661. doi: 10.18632/ aging.100494.

86. Christy B, Demaria M, Campisi J, Huang J, Jones D, Dodds SG, Williams C, Hubbard G, Livi CB, Gao X, Weintraub S, Curiel T, Sharp ZD, Hasty P. p53 and rapamycin are additive. Oncotarget. 2015; 6: 15802-15813. doi: 10.18632/ oncotarget.4602.

87. Chang GR, Chiu YS, Wu YY, Chen WY, Liao JW, Chao $\mathrm{TH}$, Mao FC. Rapamycin protects against high fat dietinduced obesity in C57BL/6J mice. J Pharmacol Sci. 2009; 109: 496-503.

88. Makki K, Taront S, Molendi-Coste O, Bouchaert E, Neve B, Eury E, Lobbens S, Labalette M, Duez H, Staels B, Dombrowicz D, Froguel P, Wolowczuk I. Beneficial metabolic effects of rapamycin are associated with enhanced regulatory cells in diet-induced obese mice. PLoS One. 2014; 9: e92684.

89. Rovira J, Marcelo Arellano E, Burke JT, Brault Y, MoyaRull D, Bañón-Maneus E, Ramírez-Bajo MJ, GutiérrezDalmau A, Revuelta I, Quintana LF, Campistol JM, Diekmann F. Effect of mTOR inhibitor on body weight: from an experimental rat model to human transplant patients. Transpl Int. 2008; 21: 992-998.

90. Hinojosa CA, Mgbemena V, Van Roekel S, Austad SN, Miller RA, Bose S, Orihuela CJ. Enteric-delivered rapamycin enhances resistance of aged mice to pneumococcal pneumonia through reduced cellular senescence. Exp Gerontol. 2012; 47: 958-965.

91. Mannick JB, Del Giudice G, Lattanzi M, Valiante NM, Praestgaard J, Huang B, Lonetto MA, Maecker HT, Kovarik J, Carson S, Glass DJ, Klickstein LB. mTOR inhibition improves immune function in the elderly. Sci Transl Med. 2014; 6: 268ra179.

92. Kennedy B, Pennypacker JK. Aging intervantions get human. Oncotarget. 2015; 6: 590-591. doi: 10.18632/ oncotarget. 3173 .

93. Blagosklonny MV. Paradoxes of aging. Cell Cycle. 2007; 6: 2997-3003.

94. Blagosklonny MV. Validation of anti-aging drugs by treating age-related diseases. Aging (Albany NY). 2009; 1 : 281-288. doi: 10.18632/aging.100034. 
95. Blagosklonny MV. Rapamycin extends life- and health span because it slows aging. Aging (Albany NY). 2013; 5: 592598. doi: 10.18632/aging.100591.

96. Demidenko ZN, Korotchkina LG, Gudkov AV, Blagosklonny MV. Paradoxical suppression of cellular senescence by p53. Proc Natl Acad Sci U S A. 2010; 107: 9660-9664.

97. Leontieva OV, Natarajan V, Demidenko ZN, Burdelya LG, Gudkov AV, Blagosklonny MV. Hypoxia suppresses conversion from proliferative arrest to cellular senescence. Proc Natl Acad Sci U S A. 2012; 109: 13314-13318.

98. Leontieva OV, Demidenko ZN, Blagosklonny MV. Contact inhibition and high cell density deactivate the mammalian target of rapamycin pathway, thus suppressing the senescence program. Proc Natl Acad Sci U S A. 2014; 111: 8832-8837.

99. Leontieva OV, Blagosklonny MV. DNA damaging agents and p53 do not cause senescence in quiescent cells, while consecutive re-activation of mTOR is associated with conversion to senescence. Aging (Albany NY). 2010; 2: 924-935. doi: 10.18632/aging.100265.

100. Dulic V. Senescence regulation by mTOR. Methods Mol Biol. 2013; 965: 15-35.

101. Iglesias-Bartolome R, Patel V, Cotrim A, Leelahavanichkul K, Molinolo AA, Mitchell JB, Gutkind JS. mTOR inhibition prevents epithelial stem cell senescence and protects from radiation-induced mucositis. Cell Stem Cell. 2012; 11: 401414.

102. Serrano M. Dissecting the role of mTOR complexes in cellular senescence. Cell Cycle. 2012; 11: 2231-2232.

103. Cho S, Hwang ES. Status of mTOR activity may phenotypically differentiate senescence and quiescence. Mol Cells. 2012; 33: 597-604.

104. Luo Y, Li L, Zou P, Wang J, Shao L, Zhou D, Liu L. Rapamycin enhances long-term hematopoietic reconstitution of ex vivo expanded mouse hematopoietic stem cells by inhibiting senescence. Transplantation. 2014; 97: 20-29.

105. Halicka HD, Zhao H, Li J, Lee YS, Hsieh TC, Wu JM, Darzynkiewicz Z. Potential anti-aging agents suppress the level of constitutive mTOR- and DNA damage- signaling. Aging (Albany NY). 2012; 4: 952-965. doi: 10.18632/ aging. 100521 .

106. Selman C, Sinclair A, Pedroni SM, Irvine EE, Michie AM, Withers DJ. Evidence that hematopoietic stem cell function is preserved during aging in long-lived S6K1 mutant mice. Oncotarget. 2016; 7:29937-29943. doi: 10.18632/ oncotarget.8729.

107. Leontieva OV, Demidenko ZN, Blagosklonny MV. Dual mTORC1/C2 inhibitors suppress cellular geroconversion (a senescence program). Oncotarget. 2015; 6: 23238-23248. doi: 10.18632/oncotarget.4836.

108. Sousa-Victor P, Garcia-Prat L, Munoz-Canoves P. Dual mTORC1/C2 inhibitors: gerosuppressors with potential anti-aging effect. Oncotarget. 2015; 6: 23052-23054. doi: 10.18632/oncotarget.5563.

109. Walters HE, Deneka-Hannemann S, Cox LS. Reversal of phenotypes of cellular senescence by pan-mTOR inhibition. Aging (Albany NY). 2016; 8: 231-244. doi: 10.18632/ aging. 100872 .

110. Gu Z, Tan W, Ji J, Feng G, Meng Y, Da Z, Guo G, Xia Y, Zhu X, Shi G, Cheng C. Rapamycin reverses the senescent phenotype and improves immunoregulation of mesenchymal stem cells from MRL/lpr mice and systemic lupus erythematosus patients through inhibition of the mTOR signaling pathway. Aging (Albany NY). 2016; 8: 1102-1114. doi: 10.18632/aging.100925.

111. Kaeberlein M, Powers RW 3rd, Steffen KK, Westman EA, Hu D, Dang N, Kerr EO, Kirkland KT, Fields S, Kennedy BK. Regulation of yeast replicative life span by TOR and Sch9 in response to nutrients. Science. 2005; 310: 1193 1196.

112. Powers RW 3rd, Kaeberlein M, Caldwell SD, Kennedy BK, Fields S. Extension of chronological life span in yeast by decreased TOR pathway signaling. Genes Dev. 2006; 20 : 174-184.

113. Kapahi P, Zid BM, Harper T, Koslover D, Sapin V, Benzer S. Regulation of lifespan in Drosophila by modulation of genes in the TOR signaling pathway. Curr Biol. 2004; 14 : 885-890.

114. Scialo F, Sriram A, Naudi A, Ayala V, Jove M, Pamplona R, Sanz A. Target of rapamycin activation predicts lifespan in fruit flies. Cell Cycle. 2015; 14: 2949-2958.

115. Moskalev AA, Shaposhnikov MV. Pharmacological Inhibition of Phosphoinositide 3 and TOR Kinases Improves Survival of Drosophila melanogaster. Rejuvenation Res. 2010; 13: 246-247.

116. Bjedov I, Toivonen JM, Kerr F, Slack C, Jacobson J, Foley A, Partridge L. Mechanisms of life span extension by rapamycin in the fruit fly Drosophila melanogaster. Cell Metab. 2010; 11: 35-46.

117. Danilov A, Shaposhnikov M, Plyusnina E, Kogan V, Fedichev P, Moskalev A. Selective anticancer agents suppress aging in Drosophila. Oncotarget. 2013; 4: 15071526. doi: 10.18632/oncotarget.1272.

118. Wang A, Mouser J, Pitt J, Promislow D, Kaeberlein M. Rapamycin enhances survival in a Drosophila model of mitochondrial disease. Oncotarget. 2016; 7: 80131-80139. doi: 10.18632/oncotarget.12560.

119. Robida-Stubbs S, Glover-Cutter K, Lamming DW, Mizunuma M, Narasimhan SD, Neumann-Haefelin E, Sabatini DM, Blackwell TK. TOR signaling and rapamycin influence longevity by regulating SKN-1/Nrf and DAF-16/ FoxO. Cell Metab. 2012; 15: 713-724.

120. Morrisett JD, Abdel-Fattah G, Hoogeveen R, Mitchell E, Ballantyne CM, Pownall HJ, Opekun AR, Jaffe JS, Oppermann S, Kahan BD. Effects of sirolimus on plasma lipids, lipoprotein levels, and fatty acid metabolism in renal 
transplant patients. J Lipid Res. 2002; 43: 1170-1180.

121. Morrisett JD, Abdel-Fattah G, Kahan BD. Sirolimus changes lipid concentrations and lipoprotein metabolism in kidney transplant recipients. Transplant Proc. 2003; 35: 143S-150S.

122. Liu Y, Diaz V, Fernandez E, Strong R, Ye L, Baur JA, Lamming DW, Richardson A, Salmon AB. Rapamycininduced metabolic defects are reversible in both lean and OBESE mice. Aging (Albany NY). 2014; 6: 742-754. doi: 10.18632/aging. 100688 .

123. Ross C, Salmon A, Strong R, Fernandez E, Javors M, Richardson A, Tardif S. Metabolic consequences of longterm rapamycin exposure on common marmoset monkeys (Callithrix jacchus). Aging (Albany NY). 2015; 7: 964-973. doi: 10.18632/aging.100843.

124. Leung LY, Lim HK, Abell MW, Zimmerman JJ. Pharmacokinetics and Metabolic Disposition of Sirolimus in Healthy Male Volunteers After a Single Oral Dose. Drug Monit. 2006; 28: 51-61.

125. Leelahavanichkul A, Areepium N, Vadcharavivad S, Praditpornsilpa K, Avihingsanon Y, Karnjanabuchmd T, Eiam-Ong S, Tungsanga K. Pharmacokinetics of sirolimus in Thai healthy volunteers. J Med Assoc Thai. 2005; 88: S157-162.

126. Veroux M, Corona D, Veroux P. Pregnancy under everolimus-based immunosuppression. Transpl Int. 2011; 24: e115-117.

127. Sifontis NM, Coscia LA, Constantinescu S, Lavelanet AF, Moritz MJ, Armenti VT. Pregnancy outcomes in solid organ transplant recipients with exposure to mycophenolate mofetil or sirolimus. Transplantation. 2006; 82: 1698-1702.

128. Singh M, Jensen MD, Lerman A, Kushwaha S, Rihal CS, Gersh BJ, Behfar A, Tchkonia T, Thomas RJ, Lennon RJ, Keenan LR, Moore AG, Kirkland JL. Effect of LowDose Rapamycin on Senescence Markers and Physical Functioning in Older Adults with Coronary Artery Disease: Results of a Pilot Study. J Frailty Aging. 2016; 5: 204-207.

129. Blagosklonny MV. Rapamycin-induced glucose intolerance: Hunger or starvation diabetes. Cell Cycle. 2011; 10: 4217 4224.

130. Blagosklonny MV. Once again on rapamycin-induced insulin resistance and longevity: despite of or owing to. Aging (Albany NY). 2012; 4: 350-358. doi: 10.18632/ aging. 100461.

131. Reifsnyder PC, Doty R, Harrison DE. Rapamycin ameliorates nephropathy despite elevating hyperglycemia in a polygenic mouse model of type 2 diabetes, NONcNZO10/ LtJ. PLoS One. 2014; 9: e114324.

132. Murakami N, Riella LV, Funakoshi T. Risk of metabolic complications in kidney transplantation after conversion to mTOR inhibitor: a systematic review and meta-analysis. Am J Transplant. 2014; 14: 2317-2327.

133. Kahan BD. Efficacy of sirolimus compared with azathioprine for reduction of acute renal allograft rejection: a randomised multicentre study. The Rapamune US Study Group. Lancet. 2000; 356: 194-202.

134. Krebs M, Brunmair B, Brehm A, Artwohl M, Szendroedi J, Nowotny P, Roth E, Fürnsinn C, Promintzer M, Anderwald C, Bischof M, Roden M. The Mammalian target of rapamycin pathway regulates nutrient-sensitive glucose uptake in man. Diabetes. 2007; 56: 1600-1607.

135. Vodenik B, Rovira J, Campistol JM. Mammalian target of rapamycin and diabetes: what does the current evidence tell us? Transplant Proc. 2009; 41: S31-38.

136. Dil'man VM, Riabov SI, Tsyrlina EV, Kirsanov AI, Kovaleva IG. [A decrease in body weight, cholesterol and blood sugar under the influence of phenformin (phenylbiguanide) in patients with cancer and atherosclerosis]. [Article in Russian]. Vopr Onkol. 1972; 18: 84-86.

137. Dilman VM, Berstein LM, Zabezhinski MA, Alexandrov VA, Bobrov JF, Pliss GB. Inhibition of DMBA-induced carcinogenesis by phenformin in the mammary gland of rats. Arch Geschwulstforsch. 1978; 48: 1-8.

138. Dilman VM, Anisimov VN. Effect of treatment with phenformin, diphenylhydantoin or L-dopa on life span and tumour incidence in $\mathrm{C} 3 \mathrm{H} / \mathrm{Sn}$ mice. Gerontology. 1980; 26 : 241-246.

139. Anisimov VN, Berstein LM, Egormin PA, Piskunova TS, Popovich IG, Zabezhinski MA, Kovalenko IG, Poroshina TE, Semenchenko AV, Provinciali M, Re F, Franceschi C. Effect of metformin on life span and on the development of spontaneous mammary tumors in HER-2/neu transgenic mice. Exp Gerontol. 2005; 40: 685-693.

140. Anisimov VN, Egormin PA, Bershtein LM, Zabezhinskii MA, Piskunova TS, Popovich IG, Semenchenko AV. Metformin decelerates aging and development of mammary tumors in HER-2/neu transgenic mice. Bull Exp Biol Med. 2005; 139: 721-723.

141. Anisimov VN, Berstein LM, Egormin PA, Piskunova TS, Popovich IG, Zabezhinski MA, Tyndyk ML, Yurova MV, Kovalenko IG, Poroshina TE, Semenchenko AV. Metformin slows down aging and extends life span of female SHR mice. Cell Cycle. 2008; 7: 2769-2773.

142. Engelman JA, Cantley LC. Chemoprevention meets glucose control. Cancer Prev Res (Phila). 2010; 3: 1049-1052.

143. Martin-Montalvo A, Mercken EM, Mitchell SJ, Palacios HH, Mote PL, Scheibye-Knudsen M, Gomes AP, Ward TM, Minor RK, Blouin MJ, Schwab M, Pollak M, Zhang Y, et al. Metformin improves healthspan and lifespan in mice. Nat Commun. 2013; 4: 2192.

144. Moiseeva O, Deschenes-Simard X, Pollak M, Ferbeyre G. Metformin, aging and cancer. Aging (Albany NY). 2013; 5: 330-331. doi: 10.18632/aging.100556.

145. Anisimov VN. Metformin: do we finally have an anti-aging drug? Cell Cycle. 2013; 12: 3483-3489.

146. Berstein LM. Metformin in obesity, cancer and aging: addressing controversies. Aging (Albany NY). 2012; 4: 
320-329. doi: 10.18632/aging.100455.

147. Dil'man VM, Bershtein LM, Tsyrlina EV, Bobrov Iu F, Kovaleva IG. [Correction of endocrine-metabolic disorders in oncologic patients. The effect of biguanides (phenformin and adebita), miskleron and diphenin]. [Article in Russian]. Vopr Onkol. 1975; 21: 33-39.

148. Cabreiro F, Au C, Leung KY, Vergara-Irigaray N, Cocheme HM, Noori T, Weinkove D, Schuster E, Greene ND, Gems D. Metformin retards aging in C. elegans by altering microbial folate and methionine metabolism. Cell. 2013; 153: 228-239.

149. Onken B, Driscoll M. Metformin induces a dietary restriction-like state and the oxidative stress response to extend C. elegans Healthspan via AMPK, LKB1, and SKN1. PLoS One. 2010; 5: e8758.

150. Evans JM, Donnelly LA, Emslie-Smith AM, Alessi DR, Morris $\mathrm{AD}$. Metformin and reduced risk of cancer in diabetic patients. BMJ. 2005; 330: 1304-1305.

151. Koch L. Cancer: Long-term use of metformin could protect against breast cancer. Nat Rev Endocrinol. 2010; 6: 356.

152. Libby G, Donnelly LA, Donnan PT, Alessi DR, Morris $\mathrm{AD}$, Evans JM. New users of metformin are at low risk of incident cancer: a cohort study among people with type 2 diabetes. Diabetes Care. 2009; 32: 1620-1625.

153. Berstein LM. Modern approach to metabolic rehabilitation of cancer patients: biguanides (phenformin and metformin) and beyond. Future Oncol. 2010; 6: 1313-1323.

154. Cufi S, Corominas-Faja B, Lopez-Bonet E, Bonavia R, Pernas S, Lopez IA, Dorca J, Martinez S, Lopez NB, Fernandez SD, Cuyas E, Visa J, Rodriguez-Gallego E, et al. Dietary restriction-resistant human tumors harboring the PIK3CA-activating mutation H1047R are sensitive to metformin. Oncotarget. 2013; 4: 1484-1495. doi: 10.18632/ oncotarget.1234.

155. Memmott RM, Mercado JR, Maier CR, Kawabata S, Fox $\mathrm{SD}$, Dennis PA. Metformin prevents tobacco carcinogen-induced lung tumorigenesis. Cancer Prev Res (Phila). 2010; 3: 1066-1076.

156. Gosmanova EO, Canada RB, Mangold TA, Rawls WN, Wall BM. Effect of metformin-containing antidiabetic regimens on all-cause mortality in veterans with type 2 diabetes mellitus. Am J Med Sci. 2008; 336: 241-247.

157. Ng TP, Feng L, Yap KB, Lee TS, Tan CH, Winblad B. Long-term metformin usage and cognitive function among older adults with diabetes. J Alzheimers Dis. 2014; 41: 6168.

158. Oaklander M. Can a diabetes drug cure aging? Time. 187: 90.

159. Novelle MG, Ali A, Dieguez C, Bernier M, de Cabo R. Metformin: A Hopeful Promise in Aging Research. Cold Spring Harb Perspect Med. 2016; 6:a025932.

160. Pollak MN. Investigating metformin for cancer prevention and treatment: the end of the beginning. Cancer Discov. 2012; 2: 778-790.
161. Zhang ZJ, Zheng ZJ, Kan H, Song Y, Cui W, Zhao G, Kip KE. Reduced risk of colorectal cancer with metformin therapy in patients with type 2 diabetes: a meta-analysis. Diabetes Care. 2011; 34: 2323-2328.

162. Palomba S, Orio FJ, Falbo A, Russo T, Tolino A, Zullo F. Clomiphene citrate versus metformin as first-line approach for the treatment of anovulation in infertile patients with polycystic ovary syndrome. J Clin Endocrinol Metab. 2007; 92: 3498-3503.

163. Cheang KI, Sharma ST, Nestler JE. Is metformin a primary ovulatory agent in patients with polycystic ovary syndrome? Gynecol Endocrinol. 2006; 22: 595-604.

164. Leontieva OV, Blagosklonny MV. M(o)TOR of pseudohypoxic state in aging: Rapamycin to the rescue. Cell Cycle. 2014; 13 :509-515.

165. Saha A, Blando J, Tremmel L, DiGiovanni J. Effect of Metformin, Rapamycin, and Their Combination on Growth and Progression of Prostate Tumors in HiMyc Mice. Cancer Prev Res (Phila). 2015; 8: 597-606.

166. Yu G, Fang W, Xia T, Chen Y, Gao Y, Jiao X, Huang S, Wang J, Li Z, Xie K. Metformin potentiates rapamycin and cisplatin in gastric cancer in mice. Oncotarget. 2015; 6: 12748-12762. doi: 10.18632/oncotarget.3327.

167. Basso N, Paglia N, Stella I, de Cavanagh EM, Ferder L, del Rosario Lores Arnaiz M, Inserra F. Protective effect of the inhibition of the renin-angiotensin system on aging. Regul Pept. 2005; 128: 247-252.

168. Basso N, Cini R, Pietrelli A, Ferder L, Terragno NA, Inserra F. Protective effect of long-term angiotensin II inhibition. Am J Physiol Heart Circ Physiol. 2007; 293: H1351-1358.

169. Benigni A, Corna D, Zoja C, Sonzogni A, Latini R, Salio M, Conti S, Rottoli D, Longaretti L, Cassis P, Morigi M, Coffman TM, Remuzzi G. Disruption of the Ang II type 1 receptor promotes longevity in mice. J Clin Invest. 2009; 119: 524-530.

170. Benigni A, Orisio S, Noris M, Iatropoulos P, Castaldi D, Kamide K, Rakugi H, Arai Y, Todeschini M, Ogliari G, Imai E, Gondo Y, Hirose N, et al. Variations of the angiotensin II type 1 receptor gene are associated with extreme human longevity. Age (Dordr). 2013; 35: 9931005.

171. Linz W, Heitsch H, Scholkens BA, Wiemer G. Long-term angiotensin II type 1 receptor blockade with fonsartan doubles lifespan of hypertensive rats. Hypertension. 2000; 35: 908-913.

172. Linz W, Jessen T, Becker RH, Scholkens BA, Wiemer G. Long-term ACE inhibition doubles lifespan of hypertensive rats. Circulation. 1997; 96: 3164-3172.

173. Santos EL, de Picoli Souza K, da Silva ED, Batista EC, Martins PJ, D'Almeida V, Pesquero JB. Long term treatment with ACE inhibitor enalapril decreases body weight gain and increases life span in rats. Biochem Pharmacol. 2009; 78: 951-958.

174. Takai S, Jin D, Sakaguchi M, Miyazaki M. Significant 
target organs for hypertension and cardiac hypertrophy by angiotensin-converting enzyme inhibitors. Hypertens Res. 2004; 27: 213-219.

175. Huang CC, Chan WL, Chen YC, Chen TJ, Lin SJ, Chen JW, Leu HB. Angiotensin II receptor blockers and risk of cancer in patients with systemic hypertension. Am J Cardiol. 2011; 107: 1028-1033.

176. Krysiak R, Sierant M, Marek B, Bienek R, Okopien B. The effect of angiotensin-converting enzyme inhibitors on plasma adipokine levels in normotensive patients with coronary artery disease. Endokrynol Pol. 2010; 61: 280287.

177. McAlister FA. Angiotensin-converting enzyme inhibitors or angiotensin receptor blockers are beneficial in normotensive atherosclerotic patients: a collaborative meta-analysis of randomized trials. Eur Heart J. 2012; 33: 505-514.

178. Tchkonia T, Zhu Y, van Deursen J, Campisi J, Kirkland JL. Cellular senescence and the senescent secretory phenotype: therapeutic opportunities. J Clin Invest. 2013; 123: 966-972.

179. Lopez-Otin C, Blasco MA, Partridge L, Serrano M, Kroemer G. The hallmarks of aging. Cell. 2013; 153: 11941217.

180. Thun MJ, Jacobs EJ, Patrono C. The role of aspirin in cancer prevention. Nat Rev Clin Oncol. 9: 259-267.

181. Danilov A, Shaposhnikov M, Shevchenko O, Zemskaya N, Zhavoronkov A, Moskalev A. Influence of non-steroidal anti-inflammatory drugs on Drosophila melanogaster longevity. Oncotarget. 2015; 6: 19428-19444. doi: 10.18632/oncotarget.5118.

182. Ayyadevara S, Bharill P, Dandapat A, Hu C, Khaidakov M, Mitra S, Shmookler Reis RJ, Mehta JL. Aspirin inhibits oxidant stress, reduces age-associated functional declines, and extends lifespan of Caenorhabditis elegans. Antioxid Redox Signal. 2013; 18: 481-490.

183. Wan QL, Zheng SQ, Wu GS, Luo HR. Aspirin extends the lifespan of Caenorhabditis elegans via AMPK and DAF-16/ FOXO in dietary restriction pathway. Exp Gerontol. 2013; 48: 499-506.

184. Strong R, Miller RA, Astle CM, Floyd RA, Flurkey K, Hensley KL, Javors MA, Leeuwenburgh C, Nelson JF, Ongini E, Nadon NL, Warner HR, Harrison DE. Nordihydroguaiaretic acid and aspirin increase lifespan of genetically heterogeneous male mice. Aging Cell. 2008; 7 : 641-650.

185. Renna NF, Vazquez MA, Lama MC, Gonzalez ES, Miatello RM. Effect of chronic aspirin administration on an experimental model of metabolic syndrome. Clin Exp Pharmacol Physiol. 2009; 36: 162-168.

186. Bulckaen H, Prevost G, Boulanger E, Robitaille G, Roquet V, Gaxatte C, Garcon G, Corman B, Gosset P, Shirali P, Creusy C, Puisieux F. Low-dose aspirin prevents agerelated endothelial dysfunction in a mouse model of physiological aging. Am J Physiol Heart Circ Physiol. 2008; 294: H1562-1570.
187. Phillips T, Leeuwenburgh C. Lifelong aspirin supplementation as a means to extending life span. Rejuvenation Res. 2004; 7: 243-251.

188. Burn J, Gerdes AM, Macrae F, Mecklin JP, Moeslein G, Olschwang S, Eccles D, Evans DG, Maher ER, Bertario L, Bisgaard ML, Dunlop MG, Ho JW, et al. Long-term effect of aspirin on cancer risk in carriers of hereditary colorectal cancer: an analysis from the CAPP2 randomised controlled trial. Lancet. 2011; 378: 2081-2087.

189. Flossmann E, Rothwell PM. Effect of aspirin on longterm risk of colorectal cancer: consistent evidence from randomised and observational studies. Lancet. 2007; 369: 1603-1613.

190. Jacobs EJ, Thun MJ, Bain EB, Rodriguez C, Henley SJ, Calle EE. A large cohort study of long-term daily use of adult-strength aspirin and cancer incidence. J Natl Cancer Inst. 2007; 99: 608-615.

191. Chan AT, Giovannucci EL, Meyerhardt JA, Schernhammer ES, Curhan GC, Fuchs CS. Long-term use of aspirin and nonsteroidal anti-inflammatory drugs and risk of colorectal cancer. Jama. 2005; 294: 914-923.

192. Cuzick J, Thorat MA, Bosetti C, Brown PH, Burn J, Cook NR, Ford LG, Jacobs EJ, Jankowski JA, La Vecchia C, Law M, Meyskens F, Rothwell PM, et al. Estimates of benefits and harms of prophylactic use of aspirin in the general population. Ann Oncol. 2015; 26: 47-57.

193. Thorat MA, Cuzick J. Prophylactic use of aspirin: systematic review of harms and approaches to mitigation in the general population. Eur J Epidemiol. 2015; 30: 5-18.

194. Mehta JL, Bursac Z, Hauer-Jensen M, Fort C, Fink LM. Comparison of mortality rates in statin users versus nonstatin users in a United States veteran population. Am J Cardiol. 2006; 98: 923-928.

195. Feldstein CA. Statins in hypertension: are they a new class of antihypertensive agents? Am J Ther. 2010; 17: 255-262.

196. Cifkova R, Nilsson PM. Statins and hypertension. J Hypertens. 2009; 27: 662-665.

197. Blanco S, Vaquero M, Gomez-Guerrero C, Lopez D, Egido J, Romero R. Potential role of angiotensin-converting enzyme inhibitors and statins on early podocyte damage in a model of type 2 diabetes mellitus, obesity, and mild hypertension. Am J Hypertens. 2005; 18: 557-565.

198. Gronich N, Rennert G. Beyond aspirin-cancer prevention with statins, metformin and bisphosphonates. Nat Rev Clin Oncol. 2013; 10: 625-642.

199. Spindler SR, Li R, Dhahbi JM, Yamakawa A, Mote P, Bodmer R, Ocorr K, Williams RT, Wang Y, Ablao KP. Statin treatment increases lifespan and improves cardiac health in Drosophila by decreasing specific protein prenylation. PLoS One. 2012; 7: e39581.

200. Varela I, Pereira S, Ugalde AP, Navarro CL, Suarez MF, Cau P, Cadinanos J, Osorio FG, Foray N, Cobo J, de Carlos F, Levy N, Freije JM, Lopez-Otin C. Combined treatment with statins and aminobisphosphonates extends longevity in 
a mouse model of human premature aging. Nat Med. 2008; 14: 767-772.

201. Jacobs JM, Cohen A, Ein-Mor E, Stessman J. Cholesterol, statins, and longevity from age 70 to 90 years. J Am Med Dir Assoc. 2013; 14: 883-888.

202. Legendre C, Campistol JM, Squifflet JP, Burke JT, Group. SERTS. Cardiovascular risk factors of sirolimus compared with cyclosporine: early experience from two randomized trials in renal transplantation. Transplant Proc. 2003; 35: 151S-153S.

203. Barron TI, Connolly RM, Sharp L, Bennett K, Visvanathan K. Beta blockers and breast cancer mortality: a populationbased study. J Clin Oncol. 2011; 29: 2635-2644.

204. London WT, McGlynn KA. Can propranalol prevent hepatocellular carcinoma? Cancer Prev Res (Phila). 2012; 5: 989-991.

205. Powe DG, Voss MJ, Zanker KS, Habashy HO, Green AR, Ellis IO, Entschladen F. Beta-blocker drug therapy reduces secondary cancer formation in breast cancer and improves cancer specific survival. Oncotarget. 2010; 1: 628-638. doi: 10.18632/oncotarget.101009.

206. Schuller HM. Beta-adrenergic signaling, a novel target for cancer therapy? Oncotarget. 2010; 1: 466-469. doi: 10.18632/oncotarget.101102.

207. Ghosh PM, Shu ZJ, Zhu B, Lu Z, Ikeno Y, Barnes JL, Yeh CK, Zhang BX, Katz MS, Kamat A. Role of beta-adrenergic receptors in regulation of hepatic fat accumulation during aging. J Endocrinol. 213: 251-261.

208. Spindler SR, Mote PL, Li R, Dhahbi JM, Yamakawa A, Flegal JM, Jeske DR, Lublin AL. beta1-Adrenergic receptor blockade extends the life span of Drosophila and long-lived mice. Age (Dordr). 2013; 35: 2099-2109.

209. Carson CC, Rosenberg M, Kissel J, Wong DG. Tadalafil - a therapeutic option in the management of BPH-LUTS. Int J Clin Pract. 2014; 68: 94-103.

210. Das A, Durrant D, Salloum F, Xi L, Kukreja R. PDE5 inhibitors as therapeutics for heart disease, diabetes and cancer. Pharmacol Ther. 2015; 147: 12-21.

211. Ribaudo G, Pagano M, Bova S, Zagotto G. New Therapeutic Applications of Phosphodiesterase 5 Inhibitors (PDE5-Is). Curr Med Chem. 2016; 23: 1239-1249.

212. Armani A, Marzolla V, Rosano GM, Fabbri A, Caprio M. Phosphodiesterase type 5 (PDE5) in the adipocyte: a novel player in fat metabolism? Trends Endocrinol Metab. 2011; 22: 404-411.

213. Varma A, Das A, Hoke N, Durrant D, Salloum F, Kukreja R. Anti-inflammatory and cardioprotective effects of tadalafil in diabetic mice. PLoS One. 2012; 7: e45243.

214. Hirose T, Nakano Y, Nagamatsu Y, Misumi T, Ohta H, Ohshima Y. Cyclic GMP-dependent protein kinase EGL-4 controls body size and lifespan in C elegans. Development. 2003; 130: 1089-1099.

215. Hahm J, Kim S, Paik YK. Endogenous cGMP regulates adult longevity via the insulin signaling pathway in
Caenorhabditis elegans. Aging Cell. 2009; 8: 473-483.

216. Montorsi F, Verheyden B, Meuleman E, Jünemann KP, Moncada I, Valiquette L, Casabé A, Pacheco C, Denne J, Knight J, Segal S, Watkins VS. Long-term safety and tolerability of tadalafil in the treatment of erectile dysfunction. Eur Urol. 2004; 45: 339-344.

217. Galiè N, Barberà JA, Frost AE, Ghofrani HA, Hoeper MM, McLaughlin VV, Peacock AJ, Simonneau G, Vachiery JL, Grünig E, Oudiz RJ, Vonk-Noordegraaf A, White RJ, et al. Initial Use of Ambrisentan plus Tadalafil in Pulmonary Arterial Hypertension. N Engl J Med. 2015; 373: 834-844.

218. Hill K, Eckhauser A, Marney A, Brown N. Phosphodiesterase 5 inhibition improves beta-cell function in metabolic syndrome. Diabetes Care. 2009; 32: 857-859.

219. Ho J, Arora P WG, Ghorbani A, Guanaga DP, Dhakal BP, Nathan DI, Buys ES, Florez JC, Newton-Cheh C, Lewis GD, Wang TJ. Effect of phosphodiesterase inhibition on insulin resistance in obese individuals. J Am Heart Assoc. 2014; 3: e001001.

220. Houtkooper RH, Mouchiroud L, Ryu D, Moullan N, Katsyuba E, Knott G, Williams RW, Auwerx J. Mitonuclear protein imbalance as a conserved longevity mechanism. Nature. 2013; 497: 451-457.

221. Bonilla E, Contreras R, Medina-Leendertz S, Mora M, Villalobos V, Bravo Y. Minocycline increases the life span and motor activity and decreases lipid peroxidation in manganese treated Drosophila melanogaster. Toxicology. 2012; 294: 50-53.

222. Ye X, Linton JM, Schork NJ, Buck LB, Petrascheck M. A pharmacological network for lifespan extension in Caenorhabditis elegans. Aging Cell. 2014; 13: 206-215.

223. Qin Y, Zhang Q, Lee S, Zhong WL, Liu YR, Liu HJ, Zhao D, Chen S, Xiao T, Meng J, Jing XS, Wang J, Sun $B$, et al. Doxycycline reverses epithelial-to-mesenchymal transition and suppresses the proliferation and metastasis of lung cancer cells. Oncotarget. 2015; 6: 40667-40679. doi: 10.18632/oncotarget.5842.

224. Pulvino M, Chen L, Oleksyn D, Li J, Compitello G, Rossi R, Spence S, Balakrishnan V, Jordan C, Poligone B, Casulo C, Burack R, Shapiro JL, et al. Inhibition of COP9signalosome (CSN) deneddylating activity and tumor growth of diffuse large B-cell lymphomas by doxycycline. Oncotarget. 2015; 6: 14796-14813. doi: 10.18632/ oncotarget.4193.

225. Wan L, Dong H, Xu H, Ma J, Zhu Y, Lu Y, Wang J, Zhang T, Li T, Xie J, Xu B, Xie F, Gao Y, et al. Aspirin, lysine, mifepristone and doxycycline combined can effectively and safely prevent and treat cancer metastasis: prevent seeds from gemmating on soil. Oncotarget. 2015; 6: 3515735172. doi: 10.18632/oncotarget.6038.

226. Man'cheva TA, Demidov DV, Plotnikova NA, Kharitonova TV, Pashkevich IV, Anisimov VN. Melatonin and metformin inhibit skin carcinogenesis and lipid peroxidation induced by benz(a)pyrene in female mice. Bull Exp Biol 
Med. 2011; 151: 363-365.

227. Anisimov VN, Egormin PA, Piskunova TS, Popovich IG, Tyndyk ML, Yurova MN, Zabezhinski MA, Anikin IV, Karkach AS, Romanyukha AA. Metformin extends life span of HER-2/neu transgenic mice and in combination with melatonin inhibits growth of transplantable tumors in vivo. Cell Cycle. 2010; 9: 188-197.

228. Bonilla E, Medina-Leendertz S, Diaz S. Extension of life span and stress resistance of Drosophila melanogaster by long-term supplementation with melatonin. Exp Gerontol. 2002; 37: 629-638.

229. Vinogradova I, Anisimov V. Melatonin prevents the development of the metabolic syndrome in male rats exposed to different light/dark regimens. Biogerontology. 2013; 14: 401-409.

230. Leontieva OV, Blagosklonny MV. Gerosuppression by panmTOR inhibitors. Aging (Albany NY). 2016; 8: 3535-3551. doi: 10.18632/aging.101155.

231. Blagosklonny MV. Tumor suppression by p53 without apoptosis and senescence: conundrum or rapalog-like gerosuppression? Aging (Albany NY). 2012; 4: 450-455. doi: 10.18632/aging.100475.

232. Demidenko ZN, Shtutman M, Blagosklonny MV. Pharmacologic inhibition of MEK and PI-3K converges on the mTOR/S6 pathway to decelerate cellular senescence. Cell Cycle. 2009; 8: 1896-1900.

233. Leontieva OV, Demidenko ZN, Blagosklonny MV. S6K in geroconversion. Cell Cycle. 2013; 12: 3249-3252.

234. Blagosklonny MV. Selective anti-cancer agents as antiaging drugs. Cancer Biol Ther. 2013; 14:1092-1097.

235. Blagosklonny MV. Molecular damage in cancer: an argument for mTOR-driven aging. Aging (Albany NY). 2011; 3: 1130-1141. doi: 10.18632/aging.100422.

236. Blagosklonny MV. Common drugs and treatments for cancer and age-related diseases: revitalizing answers to NCI's provocative questions. Oncotarget. 2012; 3: 1711 1724. doi: 10.18632/oncotarget. 890 .

237. Yusuf S, Pais P, Afzal R, Xavier D, Teo K, Eikelboom J, Sigamani A, Mohan V, Gupta R, Thomas N. Effects of a polypill (Polycap) on risk factors in middle-aged individuals without cardiovascular disease (TIPS): a phase II, doubleblind, randomised trial. Lancet. 2009; 373: 1341-1351.

238. Lafeber M, Spiering W, van der Graaf Y, Nathoe H, Bots ML, Grobbee DE, Visseren FL. The combined use of aspirin, a statin, and blood pressure-lowering agents (polypill components) and the risk of vascular morbidity and mortality in patients with coronary artery disease. Am Heart J. 2013; 166: 282-289 e281.

239. Huffman MD, de Cates AN, Ebrahim S. Fixed-dose combination therapy (polypill) for the prevention of cardiovascular disease. Jama. 2014; 312: 2030-2031.
240. Lafeber M, Webster R, Visseren F, Bots ML, Grobbee DE, Spiering W, Rodgers A. Estimated cardiovascular relative risk reduction from fixed-dose combination pill (polypill) treatment in a wide range of patients with a moderate risk of cardiovascular disease. Eur J Prev Cardiol. 2016; 23: 12891297.

241. Hawkes N. Polypill remains the only panacea in sight for cardiovascular disease, trial organiser says. Bmj. 2012; 345: e4837.

242. Lonn E, Yusuf S. Polypill: the evidence and the promise. Curr Opin Lipidol. 2009; 20: 453-459.

243. Muntner P, Mann D, Wildman RP, Shimbo D, Fuster V, Woodward M. Projected impact of polypill use among US adults: Medication use, cardiovascular risk reduction, and side effects. Am Heart J. 2011; 161: 719-725.

244. Zeymer U, Junger C, Zahn R, Bauer T, Bestehorn K, Senges J, Gitt A. Effects of a secondary prevention combination therapy with an aspirin, an ACE inhibitor and a statin on 1-year mortality of patients with acute myocardial infarction treated with a beta-blocker. Support for a polypill approach. Curr Med Res Opin. 2011; 27: 1563-1570.

245. Blagosklonny MV. Koschei the immortal and anti-aging drugs. Cell Death Dis. 2014; 5: e1552.

246. Chueh SC, Kahan BD. Dyslipidemia in renal transplant recipients treated with a sirolimus and cyclosporine-based immunosuppressive regimen: incidence, risk factors, progression, and prognosis. Transplantation. 2003; 76: 375382.

247. Lisik W, Schoenberg L, Lasky RE, Kahan BD. Statins benefit outcomes of renal transplant recipients on a sirolimus-cyclosporine regimen. Transplant Proc. 2007; 39 : 3086-3092.

248. Fok WC, Zhang Y, Salmon AB, Bhattacharya A, Gunda R, Jones D, Ward W, Fisher K, Richardson A, Perez VI. ShortTerm Treatment With Rapamycin and Dietary Restriction Have Overlapping and Distinctive Effects in Young Mice. J Gerontol A Biol Sci Med Sci. 2013; 68:108-116.

249. Yu Z, Wang R, Fok WC, Coles A, Salmon AB, Perez VI. Rapamycin and Dietary Restriction Induce Metabolically Distinctive Changes in Mouse Liver. J Gerontol A Biol Sci Med Sci. 2015;70:410-420.

250. Blagosklonny MV. Increasing healthy lifespan by suppressing aging in our lifetime: Preliminary proposal. Cell Cycle. 2010; 9: 4788-4794.

251. Blagosklonny MV. How to save Medicare: the anti-aging remedy. Aging (Albany NY). 2012; 4: 547-552. doi: 10.18632/aging. 100479 . 